\title{
A study of acute toxicity of newly synthesized compound on adult hydrobiont Danio rerio
}

\author{
A. A. Safonov ${ }^{\star B, C, D}$, Yu. V. Karpenko ${ }^{B, C, D}$, Ye. H. Knysh (iD A,F
}

Zaporizhzhia State Medical University, Ukraine

A - research concept and design; B - collection and/or assembly of data; C - data analysis and interpretation; D - writing the article;

$\mathrm{E}$ - critical revision of the article; $\mathrm{F}$ - final approval of the article

From ancient times the people used different poisons as a treatment for diseases of different genesis. To date, almost nothing has changed. One of the main conditions for the development of a new drug is its low toxicity. Literature analysis has shown that 1,2,4-triazole-3-thione derivatives are low-toxic compounds and exhibit a wide range of pharmacological activities.

The aim of this work was the investigate acute toxicity LC $_{50}$ in vivo of sodium 2-((4-amino-5-(thiophen-2-ylmethyl)-4H-1,2,4-triazole-3-yl) thio)acetate on the Zebrafish (Danio rerio) aquatic model according to OECD instruction № 203.

Materials and methods. Determination of acute toxicity LC50 of the test compound was performed in vivo on a model of the aquatic organism Zebrafish (Danio rerio) according to the instruction OECD № 203 (Fish, Acute Toxicity Test) for testing chemical compounds (acute toxicity test on fish from 10.12.2009). It was used fish 2 months of age, $11.8 \pm 0.1 \mathrm{~mm}$ long, and weighing $2.6 \pm 0.2 \mathrm{~g}$ in the experiment. The concentration of the test compound ranged from $5.0 \mathrm{mg} / \mathrm{l}$ to $100.0 \mathrm{mg} / \mathrm{l}$. Test water-soluble compounds were dissolved in distilled water. Each mini-aquarium with a certain dose of the compound contained at least 7 individuals of Danio rerio. During the experiments, the fish were kept on a diet for a test 96 hours and their mortality was checked every 24, 48, 72 and 96 hours. Statistical analysis of the results was performed using the program Statistica 6.

Results. According to the obtained data, graphs of the dependence of the concentration on the fish mortality percentage were constructed. Then the corresponding values of $\mathrm{LC}_{50}$ sodium 2-((4-amino-5-(thiophen-2-ylmethyl)-4H-1,2,4-triazole-3-yl)thio)acetate were calculated. According to the acute toxicity of $\mathrm{LC}_{50}$ (96 hours) of sodium 2-((4-amino-5-(thiophen-2-ylmethyl)-4H-1,2,4-triazole-3-yl)thio)acetate, which according to the classification of D. R. Passino and co-authors allowed it to be classified as a moderately toxic compound.

Conclusions. The acute toxicity LC $_{50}$ in vivo of sodium 2-((4-amino-5-(thiophen-2-ylmethyl)-4H-1,2,4-triazole-3-yl)thio)acetate on the Zebrafish (Danio rerio) aquatic model was investigated. The research was conducted in accordance with the national "General Ethical Principles of Animal Experimentation" approved by the First National Congress on Bioethics and the "Bioethical Expertise of Preclinical and Other Animal Research". The highest fish mortality occurs on the last day of observation (96 hours). The highest number of Zebrafish deaths is at a minimum concentration of the substance. The acute toxicity LC $_{50}$ ( 96 hours) of the test substance was 4.5364 mg/l.

Key words: acute toxicity tests, 1,2,4-triazole, salts, heterocyclic compounds.

Current issues in pharmacy and medicine: science and practice 2021; 14 (1), 68-72

Дослідження гострої токсичності нової сполуки на дорослому гідробіонті Zebrafish (Danio rerio)

\section{А. А. Сафонов, Ю. В. Карпенко, Є. Г. Книш}

Від стародавніх часів люди використовували різні отрути для лікування захворювань різного ґенезу, і донині майже нічого не змінилось. Одна з основних умов створення нового лікарського засобу - його низька токсичність. Аналіз даних фахової літератури показав, що похідні 1,2,4-тріазол-3-тіону - малотоксичні сполуки, які проявляють широкий спектр фармакологічних активностей.

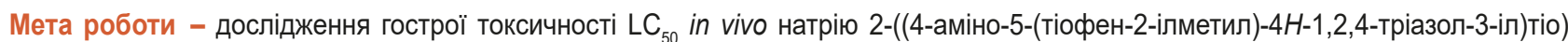
ацетату на водній моделі Zebrafish (Danio rerio) згідно з інструкцією OECD № 203.

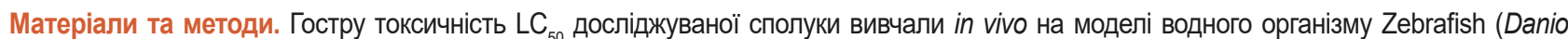
rerio) згідно з інструкцією OECD № 203 (Fish, Acute Toxicity Test) для випробування хімічних сполук (тест гострої токсичності на рибах від 10.12.2009р.). В експерименті використовували риб віком 2 місяці, завдовжки 11,8 \pm 0,1 мм і вагою 2,6 $\pm 0,2$ г. Концентрація досліджуваної сполуки становила від 5,0 мг/л до 100,0 мг/л. Водорозчинні речовини розчиняли в дистильованій воді. Кожен мініакваріум із певною дозою сполуки містив щонайменше 7 особин Danio rerio. Під час експериментів риб тримали на дієті протягом 96 годин, а їхню смертність перевіряли кожні 24, 48, 72 і 96 годин. Статистичний аналіз результатів виконали за допомогою програми Statistica 6.

ARTICLE

INFO

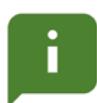

http://pharmed.

zsmu.edu.ualarticle/ view/226789
UDC 615.015.11:547.792'367'732

DOI: $10.14739 / 2409-2932.2021 .1 .226789$

Current issues in pharmacy and medicine: science and practice $2021 ; 14(1), 68-72$

Key words: acute toxicity tests, 1,2,4-triazole, salts, heterocyclic compounds.

*E-mail: 8Safonov@gmail.com

Received: 09.11.2020 // Revised: 19.11.2020 // Accepted: 27.11.2020 
Результати. За результатами дослідження побудували графіки залежності концентрації від відсотка смертності риб. Потім розрахували відповідні значення LC ${ }_{50}$ натрію 2-((4-аміно-5-(тіофен-2-ілметил)-4H-1,2,4-тріазол-3-іл)тіо)ацетату. За гострою токсичністю $\mathrm{LC}_{50}$ (96 годин) натрій 2-((4-аміно-5-(тіофен-2-ілметил)-4H-1,2,4-тріазол-3-іл)тіо)ацетату за класифікацією D. R. Passino et al. дало змогу класифікувати його як помірно токсичну сполуку.

Висновки. Вивчили гостру токсичність LC ${ }_{50}$ in vivo натрію 2-((4-аміно-5-(тіофен-2-ілметил)-4H-1,2,4-тріазол-3-іл)тіо)ацетату на водній моделі Zebrafish (Danio rerio). Дослідження здійснили згідно з національними «Загальними етичними принципами експериментів на тваринах», що затверджені Першим національним конгресом із біоетики, та «Біоетичною експертизою доклінічних та інших досліджень на тваринах». Найвищу смертність риби визначили в останній день спостереження (96 годин). Найбільшу кількість смертей риб даніо провокує мінімальна концентрація досліджуваної речовини. Гостра токсичність LC 50 (96 годин) речовини, що вивчали, становить 4,5364 мг/л.

Ключові слова: 1,2,4-тріазол, гостра токсичність, солі, гетероциклічні сполуки.

Актуальні питання фрармацевтичної і медичної науки та практики. 2021. Т. 14, № 1(35). С. 68-72

\section{Исследование острой токсичности нового соединения на взрослом гидробионте Zebrafish (Danio rerio)}

\section{А. А. Сафонов, Ю. В. Карпенко, Е. Г. Кныш}

С древних времен люди использовали различные яды для лечения заболеваний различного генеза, и на сегодня почти ничего не изменилось. Одно из основных условий создания нового лекарственного средства - его низкая токсичность. Анализ данных научной литературы показал, что производные 1,2,4-триазол-3-тиона - малотоксичные соединения, проявляют широкий спектр фрармакологических активностей.

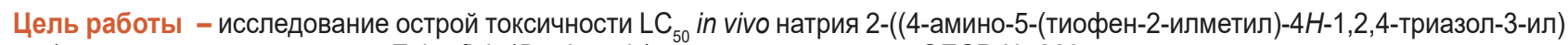
тио)ацетата на водной модели Zebrafish (Danio rerio) согласно инструкции OECD № 203.

Материалы и методы. Исследование острой токсичности LC ${ }_{50}$ тест-вещества проводили in vivo на модели водного организма Zebrafish (Danio rerio) согласно инструкции OECD № 203 (Fish, Acute Toxicity Test) для испытания химических соединений (тест острой токсичности на рыбах от 10.12.2009 г.). В эксперименте использовали рыб возрастом 2 месяца, длиной $11,8 \pm 0,1$ мм и весом 2,6 \pm 0,2 г. Концентрация исследуемого соединения составляла от 5,0 мг/л до 100,0 мг/л. Водорастворимые вещества растворяли в дистиллированной воде. Каждый мини-аквариум с определенной дозой соединения содержал не менее 7 особей Danio rerio. Во время экспериментов рыб держали на диете в течение 96 часов, а их смертность проверяли каждые 24, 48, 72 и 96 часов. Статистический анализ результатов проводили с помощью программы Statistica 6.

Результаты. По полученным данным построены графики зависимости концентрации от процента смертности рыб. Затем рассчитаны соответствующие значения LC 5 натрия 2-((4-амино-5-(тиофен-2-илметил)-4H-1,2,4-триазол-3-ил)тио)ацетата. По острой токсичности $\mathrm{LC}_{50}$ (96 часов) натрий 2-((4-амино-5-(тиофен-2-илметил)-4H-1,2,4-триазол-3-ил)тио)ацетата по классификации D. R. Passino et al. позволило классифицировать его как умеренно токсичное соединение.

Выводы. Исследована острая токсичность LC 5 in vivo натрия 2-((4-амино-5-(тиофен-2-илметил)-4H-1,2,4-триазол-3-ил)тио)ацетата на водной модели Zebrafish (Danio rerio). Исследование проведено в соответствии с национальными «Общими этическими принципами экспериментов на животных», утвержденных Первым национальным конгрессом по биоэтике, и «Биоэтической экспертизой доклинических и других исследований на животных». Самая высокая смертность рыбы отмечена в последний день наблюдения (96 часов). Наибольшее количество смертей рыб данио провоцирует минимальная концентрация исследуемого вещества. Острая токсичность LC 50 (96 часов) исследуемого вещества составляет 4,5364 мг/л.

Ключевые слова: 1,2,4-триазол, острая токсичность, соли, гетероциклические соединения.

Актуальные вопросы фармацевтической и медицинской науки и практики. 2021. Т. 14, № 1(35). С. 68-72

From ancient times the people used different poisons as a treatment for diseases of different genesis. To date, almost nothing has changed. One of the main conditions for the development of a new drug [1-4] is its low toxicity.

The study of newly synthesized compounds for acute toxicity is a necessary component for further determination of biological activity and effective dose of the future drug [5-9].

Not only mice or rats can be used to determine acute toxicity, but it can also be an aquatic organism - Zebrafish (Danio rerio) $[10,11]$.

\section{Aim}

The aim of this work was the investigate acute toxicity $\mathrm{LC}_{50}$ in vivo of sodium 2-((4-amino-5-(thiophen-2-ylmethyl)-4H- 1,2,4-triazole-3-yl)thio)acetate on the Zebrafish (Danio rerio) aquatic model according to OECD instruction № 203.

\section{Materials and methods}

Determination of acute toxicity $\mathrm{LC}_{50}$ of the test compound was performed in vivo on a model of the aquatic organism Zebrafish (Danio rerio) according to the instruction OECD № 203 (Fish, Acute Toxicity Test) for testing chemical compounds (acute toxicity test on fish from 10.12.2009).

It was used fish 2 months of age, $11.8 \pm 0.1 \mathrm{~mm}$ long, and weighing $2.6 \pm 0.2 \mathrm{~g}$ in the experiment.

The concentration of the test compound ranged from $5.0 \mathrm{mg} / 1$ to $100.0 \mathrm{mg} / \mathrm{l}$. Adults Danio rerio were stored in ventilated aquariums with carbon-filtered tap water 
$(\mathrm{pH}=7.3 \pm 0.3 ; 95 \% \mathrm{Cl})$ at a temperature of $26.5{ }^{\circ} \mathrm{C}$. This oxygen-enriched water was used for experiments. Prior to the experiments, the fish were acclimatized, with a mortality rate of no more than 1 in 500 individuals. Test water-soluble compounds were dissolved in distilled water. Each mini-aquarium with a certain dose of the compound contained at least 7 individuals of Danio rerio. During the experiments, the fish were kept on a diet for a test 96 hours and their mortality was checked every $24,48,72$, and 96 hours.

Statistical analysis of the results was performed using the program Statistica 6.

The degree of toxicity of the tested compounds was determined according to the classification of D. R. Passino [11].

The research was conducted in accordance with the national "General Ethical Principles of Animal Experimentation" approved by the First National Congress on Bioethics and the "Bioethical Expertise of Preclinical and Other Animal Research". These principles have been developed in accordance with the basic principles of bioethics and bioethical expertise in the interests of human protection and the entire biological diversity of the world. They are in line with the provisions of the "European Convention for the Protection of Vertebrate Animals Used for Experimental and Other Scientific Purposes".

Fish are considered dead if there are no visible movements (for example, gill movements) and if touching the tail stalk does not cause a reaction. Dead fish were removed by observation and mortality was recorded.

\section{Results}

As a result, the acute toxicity $\mathrm{LC}_{50}$ in vivo of sodium 2-((4-amino-5-(thiophen-2-ylmethyl)-4H-1,2,4-triazole-3yl)thio)acetate on the Zebrafish (Danio rerio) aquatic model was investigated.

The acute toxicity $\mathrm{LC}_{50}$ (96 hours) of sodium 2-((4-amino5-(thiophen-2-ylmethyl)-4H-1,2,4-triazole-3-yl)thio)acetate was $4.5364 \mathrm{mg} / \mathrm{l}$. It can be concluded that the compound belongs to the class of moderately toxic substances.

\section{Discussion}

Every 24, 48, 72, and 96 hours, mortality of the Zebrafish was entered in the Table 1.

After examining the mortality of animals at appropriate intervals, it is possible to draw conclusions about the relationship between "mortality - a period of time".

Table 1 shows that the highest fish mortality occurs on the last day of observation (96 hours). This can be explained by the accumulation of the compound in the body of animals (Fig. 1).

After 48 hours, acute poisoning occurs, as evidenced by the mortality of animals at high concentrations.

According to the obtained data, graphs of the dependence of the concentration on the fish mortality percentage were constructed (Fig. 2, 3, 4). Then the corresponding values of $\mathrm{LC}_{50}$ sodium 2-((4-amino-5-(thiophen-2-ylmethyl)-4H-1,2,4triazole-3-yl)thio)acetate were calculated.
Table 1. The dependence of the mortality of the Zebrafish on the substance concentration

\begin{tabular}{|l|l|l|l|l|}
\multirow{2}{*}{$\begin{array}{l}\text { Concentration, } \\
\text { mg/l }\end{array}$} & \multicolumn{4}{|l}{ Number of deaths / \% } \\
\cline { 2 - 5 } 5 & 24 hours & 48 hours & 72 hours & 96 hours \\
\hline 5 & 0 & $2 / 29$ & $2 / 29$ & $3 / 42$ \\
\hline 10 & 0 & 0 & $1 / 14$ & 0 \\
\hline 18 & 0 & 0 & 0 & $2 / 29$ \\
\hline 34 & 0 & 0 & $1 / 14$ & $2 / 29$ \\
\hline 65 & 0 & $1 / 14$ & 0 & $1 / 14$ \\
\hline 100 & 0 & $1 / 14$ & 0 & $2 / 29$ \\
\hline
\end{tabular}

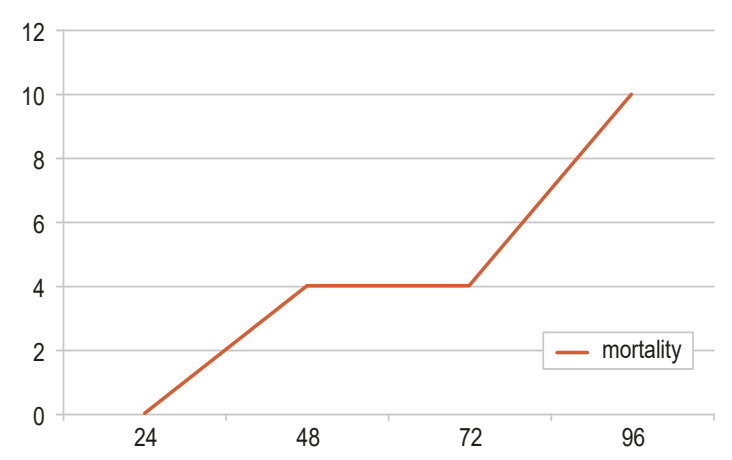

Fig. 1. The dependence of the mortality of the Zebrafish on time.

After analyzing the initial data, it can be concluded that the acute toxicity $\mathrm{LC}_{50}$ (48 hours) of the test compound was $4.1129 \mathrm{mg} / \mathrm{l}$.

Based on the above data, it can be concluded that the acute toxicity of $\mathrm{LC}_{50}$ (72 hours) of the test compound was $8.4888 \mathrm{mg} / \mathrm{l}$.

Acute toxicity $\mathrm{LC}_{50}$ (96 hours) was $4.5364 \mathrm{mg} / \mathrm{l}$.

The equation for calculating mortality taking into account a certain concentration of the compound at 96 hours:

$$
\text { Mortality }(\%)=7,8506+\frac{91,1372-7,8506}{1+\left(\frac{\text { concentration, } m g / l}{4,5364}\right)^{13,8741}}
$$

According to the acute toxicity of LC50 (96 hours) of sodium 2-((4-amino-5-(thiophen-2-ylmethyl)-4H-1,2,4-triazole-3-yl)thio)acetate, which according to the classification of D. R. Passino and co-authors allowed it to be classified as a moderately toxic compound.

At low concentrations $(5-10 \mathrm{mg} / \mathrm{l})$ of the test substance exophthalmos was observed (swelling in the orbital fossae, which leads to convexity of one or both eyes). In some cases, there was an increase in spontaneous activity.

Clinical signs in the middle range of concentrations (18-65 $\mathrm{mg} / \mathrm{l}$ ) were marked by the appearance of petechiae (spots the size of the head). Hematomas (area of blood) due to intradermal or submucosal bleeding in fish, as well as excessive mucus production, was observed in some individuals. 


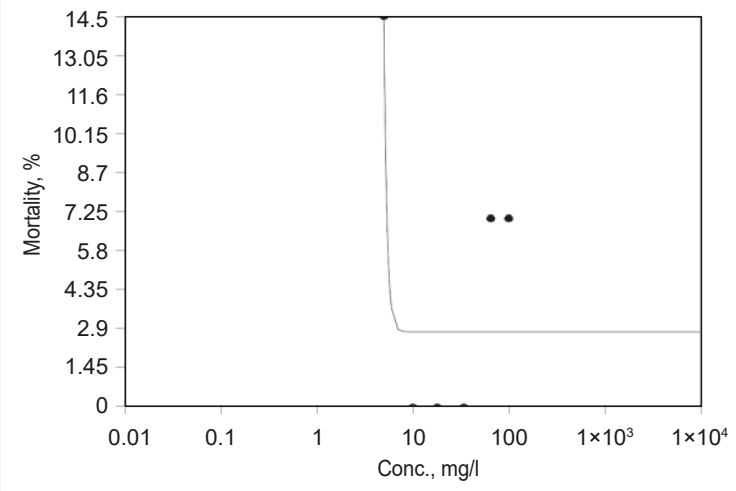

Fig. 2. Acute toxicity of compounds within 48 hours

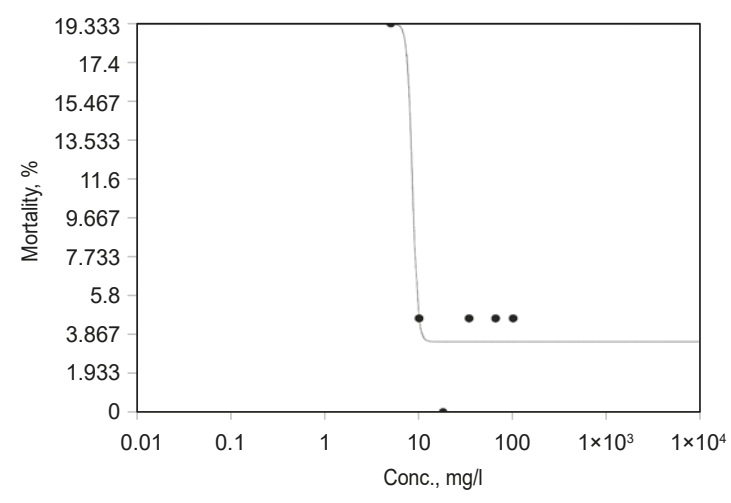

Fig. 3. Acute toxicity of compounds within 72 hours.

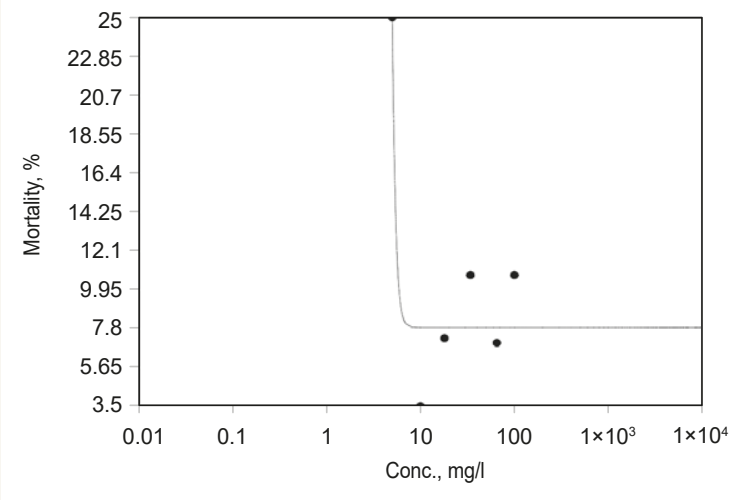

Fig. 4. Acute toxicity of compounds within 96 hours.

The effect of high concentrations $(100 \mathrm{mg} / \mathrm{l})$ on the aquatic organism Zebrafish (Danio rerio) caused abdominal edema due to fluid accumulation.

\section{Conclusions}

The acute toxicity $\mathrm{LC}_{50}$ in vivo of sodium 2-((4-amino-5(thiophen-2-ylmethyl)-4H-1,2,4-triazole-3-yl)thio)acetate on the Zebrafish (Danio rerio) aquatic model was investigated. The research was conducted in accordance with the national "General Ethical Principles of Animal Experimentation" approved by the First National Congress on Bioethics and the "Bioethical Expertise of Preclinical and Other Animal Research".

The highest fish mortality occurred on the last day of observation (96 hours).

The highest number of deaths was at minimum concentration of sodium 2-((4-amino-5-(thiophen-2-ylmethyl)-4H1,2,4-triazole-3-yl)thio)acetate.

The acute toxicity $\mathrm{LC}_{50}$ ( 96 hours) of the test substance was $4.5364 \mathrm{mg} / \mathrm{l}$. It can be concluded that the compound belongs to the class of moderately toxic substances.

\section{Funding}

The research is carried out within the SRW of Zaporizhzhia State Medical University "Synthesis, modification and study of the properties of 1,2,4-triazole derivatives to create an antimicrobial drug" state registration number 0120 U101649.

Conflicts of interest: authors have no conflict of interest to declare. Конфлікт інтересів: відсутній.

Information about authors:

Safonov A. A., PhD, Associate Professor of the Department of Natural Sciences for Foreign Students and Toxicologycal Chemistry, Zaporizhzhia State Medical University, Ukraine.

Karpenko Yu. V., PhD, Teaching Assistant of the Department of Natural Sciences for Foreign Students and Toxicological Chemistry, Zaporizhzhia State Medical University.

Knysh Ye. H., Dr. hab., Professor, Head of the Department of Management and Pharmacy Economics, Zaporizhzhia State Medical University,

Ukraine.

ORCID ID: $\underline{0000-0002-8002-6117}$

\section{Відомості про авторів:}

Сафонов А. А., канд. фарм. наук, доцент каф. природничих дисциплін для іноземних студентів та токсикологічної хімії, Запорізький державний медичний університет, Україна.

Карпенко Ю. В., канд. хім. наук, асистент каф. природничих дисциплін для іноземних студентів та токсикологічної хімії, Запорізький державний медичний університет, Україна.

Книш Є. Г., д-р фарм. наук, професор, зав. каф. управління і економіки фармації, Запорізький державний медичний університет, Україна.

\section{Сведения об авторах:}

Сафонов А. А., канд. фрарм. наук, доцент каф. естественных дисциплин для иностранных студентов и токсикологической химии, Запорожский государственный медицинский университет, Украина. Карпенко Ю. В., канд. хим. наук, ассистент каф. естественных дисциплин для иностранных студентов и токсикологической химии, Запорожский государственный медицинский университет.

Кныш Е. Г., д-р фарм. наук, профессор, зав. каф. управления и экономики фрармации, Запорожский государственный медицинский университет, Украина.

\section{References}

[1] Abd El-Wahab, H. A. A., Abdel-Rahman, H. M., Alkaramany, G. -S., \& El-Gendy, M. A. (2011). Synthesis, biological evaluation and molecular modeling study of substituted 1,2,4-triazole-3-acetic acid derivatives. Der Pharma Chemica, 3(6), 540-552.

[2] Kaplaushenko, A. H., Sameliuk, Yu. H., \& Kucheriavyi, Yu. M. (2016). Praktychne znachennia ta zastosuvannia pokhidnykh 1,2,4-triazolu [Practical value and application of derivatives of 1,2,4-triazole]. Zaporizhzhia. [in Ukrainian]. 
[3] Hulina, Yu. S., \& Kaplaushenko, A. G. (2018). Synthesis, physical and chemical properties of 5-((1H-tetrazole-1-yl)methyl)-4-R-4H-1,2,4-triazole-3-thiols and their chemical transformations. Biopharmaceutical journal, (1), 26-30.

[4] Rud, A. M., Kaplaushenko, A. G., \& Yurchenko, I. O. (2018). Synthesis, physical and chemical properties of 2-(5-(hydroxy(phenyl)methyl)4R-4H-1,2,4-triazole3-yl)thio)acetic acids and its salts. Zaporozhye medical journal, 20(1), 105-109. https://doi.org/10.14739/23101210.2018.1.122126

[5] Wu, J. W., Yin, L., Liu, Y. Q., Zhang, H., Xie, Y. F., Wang, R. L., \& Zhao, G. L. (2019). Synthesis, biological evaluation and 3D-QSAR studies of 1,2,4-triazole-5-substituted carboxylic acid bioisosteres as uric acid transporter 1 (URAT1) inhibitors for the treatment of hyperuricemia associated with gout. Bioorganic \& medicinal chemistry letters, 29(3), 383-388. https://doi.org/10.1016/i.bmcl.2018.12.036

[6] Hassan, A. A., Mohamed, N. K., Aly, A. A., Tawfeek, H. N., Brase, S., \& Nieger, M. (2019). Eschenmoser-Coupling Reaction Furnishes Diazenyl-1,2,4-triazole-5(4H)-thione Derivatives. Chemistryselect, 4(2), 465-468. https://doi.org/10.1002/slct.201802870

[7] Moreno-Fuquen, R., Arango-Daraviña, K., Becerra, D., Castillo, J. C., Kennedy, A. R., \& Macías, M. A. (2019). Catalyst- and solvent-free synthesis of 2-fluoro-N-(3-methylsulfanyl-1H-1,2,4-triazol-5-yl)benzamide through a microwave-assisted Fries rearrangement: X-ray structural and theoretical studies. Acta crystallographica. Section C, Structural chemistry, 75(Pt 3), 359-371. https://doi.org/10.1107/ S2053229619002572

[8] Hulina, Yu. S., \& Kaplaushenko, A. G. (2016). Syntez i fizyko-khimichni vlastyvosti 2-(5-(1H-tetrazol-1-ilmetyl)-4-R-4H-1,2,4-triazol-3-iltio)atsetatnykh(propanovykh), 2-, 4-(5-(1H-tetrazol-1-ilmetyl)-4-fenil-4H1,2,4-triazol-3-iltiometyl)-benzoinykh kyslot ta yikh solei [Synthesis and physical-chemical properties of 2-(5-(1H-tetrazol-1-ylmethyl)-4R-4H-1,2,4-triazol-3-yltio)-acetic (propanoic), 2-, 4-(5-(1H-tetrazol1-ylmethyl)-4-phenyl-4H-1,2,4-triazol-3-yltiometil)-benzoic acids and their salts]. Current issues in pharmacy and medicine: science and practice, (2), 32-37. [in Ukrainian]. https://doi.org/10.14739/24092932.2016.2.71115

[9] Pillai, R. R., Karrouchi, K., Fettach, S., Armaković, S., Armaković, S. J., Brik, Y., Taoufik, J., Radi, S., El Abbes Faouzi M., \& Ansar, M. (2019). Synthesis, spectroscopic characterization, reactive properties by DFT calculations, molecular dynamics simulations and biological evaluation of Schiff bases tethered 1,2,4-triazole and pyrazole rings. Journal of Molecular Structure, 1177, 47-54. https://doi.org/10.1016/i. molstruc.2018.09.037

[10] Stefanov, O. V. (Ed.). (2001). Doklinichni doslidzhennia likarskykh zasobiv [Preclinical studies of medicinal products: methodical recommendations]. Kyiv: Avicena. [in Ukrainian].

[11] OECD (2019). Test No. 203: Fish, Acute Toxicity Test, OECD Guidelines for the Testing of Chemicals, Section 2, OECD Publishing, Paris, https://doi.org/10.1787/9789264069961-en

[12] Passino, D. R. M., \& Smith, S. B. (1987). Acute bioassays and hazard evaluation of representative contaminants detected in great lakes fish. Environmental Toxicology and Chemistry, 6(11), 901-907. https://doi. org/10.1002/etc.5620061111 